\title{
The alpha-carbonic anhydrase from the thermophilic bacterium Sulfurihydrogenibium yellowstonense YO3AOP1 is highly susceptible to inhibition by sulfonamides
}

\author{
Daniela Vullo ${ }^{a}$, Viviana De Luca ${ }^{\mathrm{b}}$, Andrea Scozzafava ${ }^{\mathrm{a}}$, Vincenzo Carginale ${ }^{\mathrm{b}}$, Mosè Rossi ${ }^{\mathrm{b}, \mathrm{c}}$, \\ Claudiu T. Supuran ${ }^{\mathrm{a}, \mathrm{d}, *}$, Clemente Capasso ${ }^{\mathrm{b}, *}$ \\ ${ }^{a}$ Università degli Studi di Firenze, Polo Scientifico, Laboratorio di Chimica Bioinorganica, Rm. 188, Via della Lastruccia 3, 50019 Sesto Fiorentino (Florence), Italy \\ ${ }^{\mathrm{b}}$ Istituto di Biochimica delle Proteine, CNR, Via P. Castellino 111, 80131 Napoli, Italy \\ ${ }^{\mathrm{C}}$ Centro di Ricerca Interdipartimentale sui Biomateriali, Univ. Federico II, P-le V. Tecchio 80, 80125 Napoli, Italy \\ ${ }^{\mathrm{d}}$ Università degli Studi di Firenze, Polo Scientifico, Dipartimento di Scienze Farmaceutiche, Via Ugo Schiff 6, 50019 Sesto Fiorentino (Florence), Italy
}

\section{A R T I C L E I N F O}

\section{Article history:}

Available online 23 July 2012

\section{Keywords:}

Carbonic anhydrase

Sulfonamide

Alpha-class enzyme

Inhibitor

Sulfurihydrogenibium yellowstonense

Thermophilic bacteria

\begin{abstract}
A B S T R A C T
The $\alpha$-carbonic anhydrase (CA, EC 4.2.1.1) from the newly discovered thermophilic bacterium Sulfurihydrogenibium yellowstonense YO3AOP1 (SspCA) was investigated for its inhibition with a large series of sulfonamides and a sulfamate, the classical inhibitors of these zinc enzymes. SspCA showed an inhibition profile with these compounds very similar to that of the predominant human cytosolic isoform hCA II, and not to that of the bacterial $\alpha$-CA from Helicobacter pylori. Some clinically used drugs such as acetazolamide, methazolamide, ethoxzolamide, dichlorophenamide, dorzolamide, brinzolamide, topiramate, celecoxib and sulthiame were low nanomolar SspCA/hCA II inhibitors ( $\mathrm{K}_{\mathrm{I}} \mathrm{S}$ in the range of $\left.4.5-12.3 \mathrm{nM}\right)$ whereas simple aromatic/heterocyclic sulfonamides were less effective, micromolar inhibitors. As this highly catalytically active and thermostable enzyme may show biotechnological applications, its inhibition studies may be relevant for designing on/off systems to control its activity.
\end{abstract}

(c) 2012 Elsevier Ltd. All rights reserved.

\section{Introduction}

The genus Sulfurihydrogenibium, reported within the order Aquificales, belongs to the chemosynthetic bacterial communities living in hot springs, at temperatures of up to $110^{\circ} \mathrm{C}$, and in the presence of high hydrogensulfide concentrations (between 1 and $100 \mu \mathrm{M}) .{ }^{1}$ Sulfurihydrogenibium are chemolithotrophic, sulfide-oxidizing species and were discovered for the first time in 2003, and found in hot springs all over the world, from the Yellowstone National Park, to the Azores Islands and Japan. ${ }^{1,2}$ As many bacteria, it is presumed that they express carbonic anhydrases (CAs, EC 4.2.1.1), enzymes involved in the $\mathrm{CO}_{2}$ fixation and biosynthetic processes. In many bacteria, as well as algae and plants, the role of the various classes of CAs is well established. ${ }^{1-4}$ In fact, recently, our groups reported ${ }^{2}$ the expression and purification of a bacterial $\alpha$-CA from Sulfurihydrogenibium yellowstonense YO3AOP1. ${ }^{2}$ The enzyme has been named SspCA and investigated for its catalytic activities: (a) $\mathrm{CO}_{2}$-hydratase activity, the physiological reaction used by the bacterium to transform $\mathrm{CO}_{2}$ to bicarbonate and a

\footnotetext{
* Corresponding authors. Tel.: +39 055 4573005; fax: +39 0554573385 (C.T.S.); tel.: +39081 6132559; fax: +390816132277 (C.C.).

E-mail addresses: claudiu.supuran@unifi.it (C.T. Supuran), c.capasso@ibp.cnr.it (C. Capasso).
}

proton; (b) esterase activity, measured using 4-nitrophenylacetate as substrate. ${ }^{2}$ It has been observed that this highly thermostable enzyme (up to $70^{\circ} \mathrm{C}$ ) also shows excellent catalytic activity for both reactions mentioned above. ${ }^{2}$

In fact, CAs are a class of enzymes which evolved at least five times independently, to catalyze a simple but physiologically relevant process in all life kingdoms: carbon dioxide hydration to bicarbonate and protons. ${ }^{5-8}$ The five genetically distinct CA families known to date, are the $\alpha-, \beta-, \gamma-, \delta$ - and $\zeta$-CAs, and all of them are metalloenzymes, using $\mathrm{Zn}(\mathrm{II}), \mathrm{Cd}(\mathrm{II})$ or $\mathrm{Fe}(\mathrm{II})$ at their active sites. ${ }^{9,10}$ Bacteria, the most successful organisms on earth, encode $\alpha-, \beta-$, and/or $\gamma$-CAs, with many of them containing several different isoforms, and even enzymes from two or three distinct families. ${ }^{4-10}$ These enzymes started to be investigated in detail recently in pathogenic bacteria, in the search of antibiotics with a novel mechanism of action, since it has been demonstrated that in many such bacteria CAs are essential for the life cycle of the organism. ${ }^{10 a}$ Thus, the $\alpha$-CAs from Neisseria spp. and Helicobacter pylori as well as the $\beta$-class enzymes from Escherichia coli, Helicobacter pylori, Mycobacterium tuberculosis, Brucella spp., Streptococcus pneumoniae, Salmonella enterica and Haemophilus influenzae have been cloned and characterized in detail in the last few years. ${ }^{10 a}$ For some of them, X-ray crystal structures of the encoded CAs were also determined, and in vitro and in vivo inhibition 
studies with various classes of inhibitors, such as anions, sulfonamides and sulfamates have been reported. ${ }^{6,10 a}$ Although the bacterial CA inhibition studies are in their infancy at this moment, the cloning of more bacterial genomes may lead to the discovery of genes and proteins which may have interesting applications both in the biomedical and biotechnological fields. Here we continue our investigations on bacterial CA inhibitors, and report the first inhibition study of SsPCA with a series of sulfonamides and sulfamates, which represent the classical CA inhibitors (CAIs), some of which possess pharmacologic applications as drugs (diuretics, antiglaucoma, antiepileptic and anticancer agents). ${ }^{6}$

\section{Results and discussion}

We have previously reported some evidence ${ }^{3}$ that SspCA has a high catalytic activity for the $\mathrm{CO}_{2}$ hydration reaction (Table 1 ), with $k_{\text {cat }}$ of $9.35 \times 10^{5} \mathrm{~s}^{-1}, K_{\mathrm{m}}$ of $8.4 \mathrm{mM}$ and $k_{\text {cat }} / K_{\mathrm{m}}$ of $1.1 \times 10^{8} \mathrm{M}^{-1} \times$ $\mathrm{s}^{-1}$ (at $20^{\circ} \mathrm{C}$ and $\mathrm{pH}$ of 7.5 ). As seen from the data of Table 1 , where the kinetic parameters for two mammalian isoforms (the human (h) enzymes hCA I and II) as well as those of the bacterial best investigated $\alpha-C A$, that is hp $\alpha C A$ from the gastric pathogen H. pylori, SspCA has a relevant catalytic activity for the physiologic reaction. Whereas hCA II is three times more effective as a catalyst compared to hCA I, SspCA is in fact more than two times more effective than hCA I and more than seven times than hpaCA (based on the $k_{\text {cat }} / K_{\mathrm{m}}$ values).

Thus, we have aligned the amino acid sequence of SspCA and that of several other investigated $\alpha$-CAs from various organisms, in order to try to rationalize the kinetic data mentioned above. In Figure 1 the amino acid sequences of two mammalian (hCA I and II), one nematode (Cah-4b from Caenorhabditis elegans), ${ }^{11}$ two coral (STPCA and STPCA-2), ${ }^{12}$ and two bacterial (hp $\alpha \mathrm{CA}^{13}$ and SspCA ${ }^{3}$ ) were aligned. It may be observed that similar to the other investigated $\alpha$-CA, SspCA has the conserved three His ligands, which coordinate the $\mathrm{Zn}$ (II) ion crucial for catalysis (His94, 96 and 119, hCA I numbering system). Except for the nematode enzyme, the proton shuttle residue (His64) is also conserved in all these enzymes. This residue assists the rate-determining step of the catalytic cycle transferring a proton from the water coordinated to the $\mathrm{Zn}(\mathrm{II})$ ion to the environment, with formation of zinc hydroxide representing the nucleophilic species of the enzyme. SspCA also has the gatekeeping residues (Glu106 and Thr199) which orientate the substrate for catalysis, and are also involved in the binding of inhibitors, similar to the other $\alpha$-CAs discussed here..$^{5-10}$ All these residues are in fact conserved in all these $\alpha$-CAs of mammalian or bacterial origin.

In Figure 2, a phylogenetic analysis of the bacterial/coral/nematode/mammalian $\alpha$-CAs mentioned above is shown. It may be observed that SspCA is phylogenetically more related to the other bacterial $\alpha$-CAs considered here, that is the enzyme from $H$. pylori. This is not unexpected, but it should be mentioned that the two enzymes differ significantly for their catalytic activity. This is, in fact, well known for the human isoforms, which even if clustering together, possess a variable catalytic activity.

As sulfonamides/sulfamates constitute the main class of CAIs, and such compounds have not been investigated for their interaction with SspCA, we report here a comprehensive such study. Simple sulfonamides investigated here for the inhibition of SspCA of types 1-24 are shown below, and they incorporate the mostly used scaffolds in the drug design of sulfonamide CAIs. ${ }^{14-18}$ Derivatives AAZ-HCT are clinically used drugs: acetazolamide AAZ, methazolamide MZA, ethoxzolamide EZA and dichlorophenamide DCP, are the classical, systemically acting CAIs. ${ }^{6}$ Dorzolamide DZA and brinzolamide BRZ are topically-acting antiglaucoma agents, ${ }^{6}$ benzolamide BZA is an orphan drug belonging to this class of pharmacological agents, whereas topiramate TPM is a widely used antiepileptic drug. ${ }^{6}$ Sulpiride SLP, indisulam IND, valdecoxib VLX, celecoxib CLX, sulthiame SLT, saccharin SAC and hydrochlorothiazide HCT were recently shown by this group to belong to this class of pharmacological agents. ${ }^{6}$ Compounds $1,2,4-6,11,12,18-20$, 23 and AAZ-SLP are commercially available or were a gift from the company producing them (see Experimental section for details), whereas $\mathbf{7 - 1 0},{ }^{14} \mathbf{1 3 - 1 7},{ }^{15} \mathbf{2 1},{ }^{16} \mathbf{2 2}^{17}$ and $\mathbf{2 4},{ }^{18}$ were prepared as reported earlier by this group. Inhibition data of these sulfonamides and the sulfamate TPM against isozymes hCA I, hCAII, hpaCA and SspCA are shown in Table 2 (data for the previously reported enzymes, hCA I, hCAII and hpaCA are reported for comparison reasons).

The following structure-activity relationship (SAR) may be observed by comparing the inhibition data of SspCA with these compounds:

(i) A group of compounds, among which derivatives 1-5, 13, $14,21,22,24$, SZN and SAC, showed modest inhibitory activity against SspCA, with inhibition constants in the range of 137-876 nM (Table 2). It may be observed that they include the simple benzenesulfonamides incorporating ortho- or para- compact substituents of the amino, hydrazino, methyl or amino/hydroxyl-methyl/ethyl type, the simple heterocyclic sulfonamides 13 and 14 incorporating the thiadiazole or thiadiazoline rings as well as the two clinically used compounds with structural particularities: zonisamide the only aliphatic compound among the clinically used sulfonamides, and the sweetener saccharin, which is a secondary acylated sulfonamide. It should be noted that most these compounds are much weaker hCA I inhibitors, some of them inhibit hCA II better than SspCA, whereas they are modest hpaCA inhibitors (Table 2).

(ii) Derivatives 6-12, 19, 20, 23, as well as SLP and IND, were more effective CAIs compared to the previously discussed sulfonamides, showing inhibition constants in the range of 41.2-84.1 nM. It may be observed that the longer aminoalkyl tail present in $\mathbf{6}$ leads to a marked increase of affinity for SspCA compared to $\mathbf{5}$ and $\mathbf{2}$, which have one and

Table 1

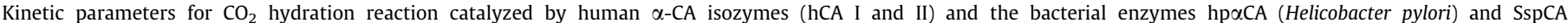

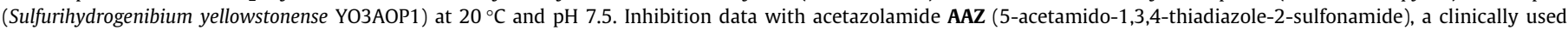
drug

\begin{tabular}{|c|c|c|c|c|c|}
\hline Enzyme & Activity level & kcat $\left(\mathrm{s}^{-1}\right)$ & $\mathrm{Km}(\mathrm{mM})$ & kcat $/ \mathrm{Km}\left(\mathrm{M}^{-1} \times \mathrm{s}^{-1}\right)$ & $\mathrm{K}_{1}$ (acetazolamide) (nM) \\
\hline hCA I ${ }^{a}$ & Medium & $2.00 \times 10^{5}$ & 4.0 & $5.0 \times 10^{7}$ & 250 \\
\hline hCA II & Very high & $1.40 \times 10^{6}$ & 9.3 & $1.5 \times 10^{8}$ & 12 \\
\hline hp $\alpha \mathrm{CA}^{\mathrm{b}}$ & Low & $2.5 \times 10^{5}$ & 16.6 & $1.5 \times 10^{7}$ & 21 \\
\hline SspCA ${ }^{c}$ & High & $9.35 \times 10^{5}$ & 8.4 & $1.1 \times 10^{8}$ & 4.5 \\
\hline
\end{tabular}

\footnotetext{
a Human recombinant isozymes, stopped flow $\mathrm{CO}_{2}$ hydrase assay method, from Ref. 2a,11a.

b From Ref 11a.

c Recombinant enzyme, stopped flow $\mathrm{CO}_{2}$ hydrase assay method, this work.
} 
hCAI

hCAII

$\mathrm{CAH}-4 \mathrm{~b}$

STPCA

STPCA-2

hpaCA

SspCA

hCAI

hCAII

CAH $-4 \mathrm{~b}$

STPCA

STPCA-2

hp $\alpha C A$

SspCA

hCAI

hCAII

CAH $-4 \mathrm{~b}$

STPCA

STPCA-2

hpaCA

SspCA

hCAI

hCAII

CAH $-4 \mathrm{~b}$

STPCA

STPCA-2

hpaCA

SspCA

hCAI

hCAII

CAH $-4 \mathrm{~b}$

STPCA

STPCA-2

hpaCA

SspCA

hCAI

hCAII

CAH $-4 b$

STPCA

STPCA-2

hpaCA

SspCA

hCAI

hCAII

$\mathrm{CAH}-4 \mathrm{~b}$

STPCA

STPCA-2

hpaCA

SspCA
---------_---_---MASPDWGY-DDKNG---PEQWSKLYP---IAN-GNNQSP -MSHHWGY-GKHNG---PEHWHKDFP---IAK-GERQSP

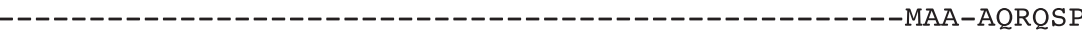
MKLSLFISSLLAMIVACPNLAESAGSWTY-RDPEG---PDTWKHHYK---DCE-GHEQSP --------MYFLWLISMIAAAMCQEYGY-MSEQGVPTPSNWSKVFP---LCG-GKFQSP ----MKKTFLIALALTASLIGAENTKWDYKNKENG---PHRWDKLHKDFEVCKSGKSQSP ---MRKILISAVLVLSSISISFAEHEWSY-EGEKG---PEHWAQLKPEFFWCK-LKNQSP

64

VDIKTSETKHDTSLKP---ISVSYNPA---TAKEI INVGHSFHVNFEDNDNRSVLKGGPF VDIDTHTAKYDPSLKP---LSVSYDQA---TSLRILNNGHAFNVEFDDSQDKAVLKGGPL IDIVPQHVCCDTDVCKADALNIDYKSG---DCCDVLVSEGGFLVNVK-RNCGTFLTANHL INIVPKDTFFEPGLAD---LVVNYEKS---VSAKLFNNGHTVQATF--LTGKSNISGGNL INIETKKVK-KKSYPD---LKISFDNPCGRVTGELLNAGHSPVVNIDSSKGGAKLSGGPL INIE--HYYHTODKAD---LOFKYAAS---KPKAVFFTHHTLKASFEPTNH INYRG---INID-KKYKVKANLPK---LNLYYKTA---KESEVVNNGHTIQINIKEDNTLNYLG---: :*

$94 \dot{96}: \dot{:}:$ is

S-DSYRLFQFHFHWGSTNEHGSEHTVDGVKYSAELHVAHWNSAKYSSLAEAASKADG-LA D-GTYRLIQFHFHWGSLDGQGSEHTVDKKKYAAELHLVHWNT-KYGDFGKAVQQPDG-LA PSSKFALAOFHAHWGSNSKEGSEHFLDGKOLSGEVHFVFWNT-SYESFNVALSKPDG-LA T-SHFRALQMHFHWGSENSRGSEHQVGGRKFPLEIHIVHYNAEKYPSVSEAVDKGDG-LA DCDEYALQQFHFHFGCENSRGSEHLIDSQAFPAQLHLVFFNK-KYETFQNAVDKPDG-LA --HDYVLDNVHFH------APMEFLINNKTRPLSAHFVHKDA------------KGRLL --EKYQLKQFHFH------TPSEHTIEKKSYPLEIHFVHKTE------------DGKIL

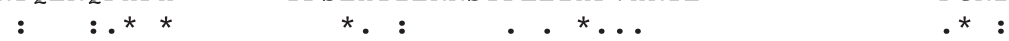

VIGVLMK-VGEANPKLQKVLDALQAIKTKGKRAPF---TNFDPSTLLP---_------VLGIFLK-VGSAKPGLQKVVDVLDS IKTKGKSADF---TNFAARGLLP----------VVGVFLK-EGKYNDNYHGLIDTVRK--ATGNATPIAMPKDFH IEHLLP-_-------VLGILVELQVQDNPVFDVMVDNLDKARYKGNEVIL---PSLQPFSFLP----------VLGVLITATCPGNRVLGSFAKKLTKI IEEGASANVTAVDGIKLNYLMPYNNKQGDEDEDD VLAIGFE-EGKENPNLDPILEGIOK------KONL---KEVALDAFLP-_-_-_- - VVGVMAK-LGKTNKELDKILNVAPA--EEGEKILD---KNLNLNNLIP---_------*: : : . . .

199

-------------------SSLD--FWTYPGSLTHPPLYESVTWI I CKESISVSSEQLAO -------------------ESLD--YWTYPGSLTTPPLLECVTWIVLKEPISVSSEQVLK --ー-ー-ー-ー-ー--------SPDKREFVTYLGSLTTPPYNECVIWTLFTEPVEVSFGQLNV ------------------HDIA-QYYTYRGSLTTPGCFESVQWFVFNHTFPISQAQLDK EDIAGDDPDAVEEEEVDAKKKIK--YYTYKGSLTTPPCYESVTWIVFKDKIKISNTQLKK -------------------KSIN--YYHFNGSLTAPPCTEGVAWFVIEEPLEVSAKQLAE -----------------KDKR--YMTYSGSLTTPPCTEGVRWIVLKKPISISKQQLEK $: \quad: * * * * * * *: \quad$ : $*$ * $*$

FRSLL-SNVEGDNAVPMQHNNRPTQPLKGRTVRASF-

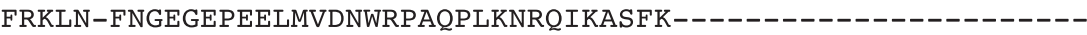
LRNII------------PANHRACQDRCDREIRSSFNFFRDLFDSEKQDTKKLPLVDNYRPVQPLYGRSVSEASNALLFPVARHQTKLWIAWDSLMTR FRKLK-AQYGGAPG-LMCDNIRPVQPLHKRKVYSVLSSRE-

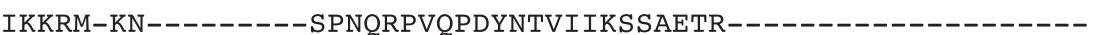
LKSVM-----------VNPNNRPVQEINSRWIIEGF-----------------------:. $\quad$ * * * * :

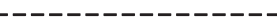

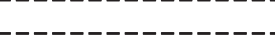

QYFMKQQSICALYQPQ

$---------------1$

-

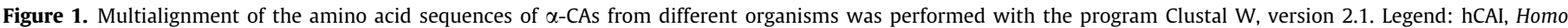

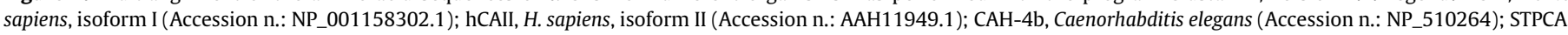

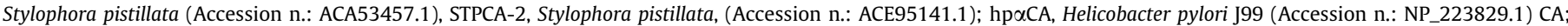

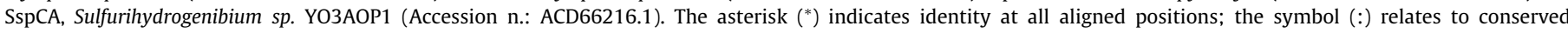

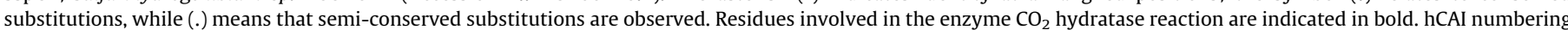

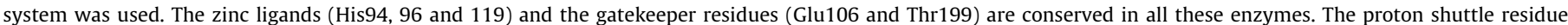
(His64) is not present in the nematode carbonic anhydrase (CAH-4b), but conserved in all the other $\alpha$-CAs considered in the sequence alignment. 


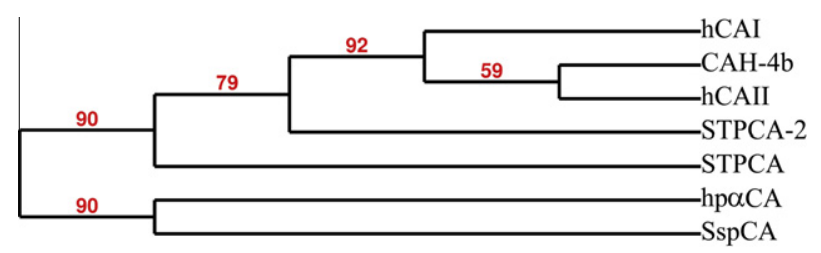

Figure 2. Phylogenetic tree was constructed using the program PhyML 3.0. Branch support values, displayed in \%, are reported at branch points. Legend: hCAI, Homo sapiens, isoform I (Accession n.: NP_001158302.1); hCAII, H. sapiens, isoform II (Accession n.: AAH11949.1); CAH-4b, Caenorhabditis elegans (Accession n.: NP_510264); STPCA, Stylophora pistillata (Accession n.: ACA53457.1), STPCA-2, Stylophora pistillata, (Accession n.: ACE95141.1); hpaCA, Helicobacter pylori J99 (Accession n.: NP_223829.1) CA; SspCA, Sulfurihydrogenibium sp. YO3AOP1 (Accession n.: ACD66216.1).

Table 2

Inhibition constants of sulfonamide inhibitors against $\alpha$-CA isozymes derived from human (hCA I and II), and the bacterial enzymes hpaCA and SspCA, at $20^{\circ} \mathrm{C}$ by a stopped flow $\mathrm{CO}_{2}$ hydrase assay ${ }^{18}$

\begin{tabular}{|c|c|c|c|c|}
\hline \multirow[t]{2}{*}{ Inhibitor } & \multicolumn{4}{|c|}{$\mathrm{KI}^{*}(\mathrm{nM})$} \\
\hline & hCA I ${ }^{a}$ & hCA II ${ }^{a}$ & hp $\alpha \mathrm{CA}^{\mathrm{b}}$ & SspCA ${ }^{c}$ \\
\hline 1 & 45400 & 295 & 426 & $707 \pm 70$ \\
\hline 2 & 25000 & 240 & 454 & $652 \pm 51$ \\
\hline 3 & 28000 & 300 & 316 & $803 \pm 64$ \\
\hline 4 & 78500 & 320 & 430 & $848 \pm 76$ \\
\hline 5 & 25000 & 170 & 873 & $350 \pm 17$ \\
\hline 6 & 21000 & 160 & 1150 & $73.0 \pm 6$ \\
\hline 7 & 8300 & 60 & 1230 & $68.3 \pm 3$ \\
\hline 8 & 9800 & 110 & 378 & $41.2 \pm 4$ \\
\hline 9 & 6500 & 40 & 452 & $75.7 \pm 6$ \\
\hline 10 & 6000 & 70 & 510 & $44.8 \pm 2$ \\
\hline 11 & 5800 & 63 & 412 & $61.2 \pm 6$ \\
\hline 12 & 8400 & 75 & 49 & $87.3 \pm 7$ \\
\hline 13 & 8600 & 60 & 323 & $137 \pm 9$ \\
\hline 14 & 9300 & 19 & 549 & $433 \pm 31$ \\
\hline 15 & 6 & 2 & 268 & $5.5 \pm 0.5$ \\
\hline 16 & 164 & 46 & 131 & $7.8 \pm 0.7$ \\
\hline 17 & 185 & 50 & 114 & $9.7 \pm 0.3$ \\
\hline 18 & 109 & 33 & 84 & $6.5 \pm 0.2$ \\
\hline 19 & 95 & 30 & 207 & $66.4 \pm 3$ \\
\hline 20 & 690 & 12 & 105 & $70.1 \pm 5$ \\
\hline 21 & 55 & 80 & 876 & $493 \pm 19$ \\
\hline 22 & 21000 & 125 & 1134 & $162 \pm 10$ \\
\hline 23 & 23000 & 133 & 1052 & $72.4 \pm 7$ \\
\hline 24 & 24000 & 125 & 541 & $695 \pm 65$ \\
\hline $\mathrm{AAZ}$ & 250 & 12 & 21 & $4.5 \pm 0.3$ \\
\hline MZA & 50 & 14 & 225 & $8.2 \pm 0.6$ \\
\hline EZA & 25 & 8 & 193 & $9.3 \pm 0.7$ \\
\hline DCP & 1200 & 38 & 378 & $8.5 \pm 0.9$ \\
\hline DZA & 50000 & 9 & 4360 & $8.0 \pm 0.7$ \\
\hline BRZ & 45000 & 3 & 210 & $12.3 \pm 1.1$ \\
\hline BZA & 15 & 9 & 315 & $8.1 \pm 0.4$ \\
\hline TPM & 250 & 10 & 172 & $6.6 \pm 0.5$ \\
\hline ZNS & 56 & 35 & 231 & $140 \pm 11$ \\
\hline SLP & 1200 & 40 & 204 & $67.4 \pm 5$ \\
\hline IND & 31 & 15 & 413 & $84.1 \pm 7$ \\
\hline VLX & 54000 & 43 & nt & $5.3 \pm 0.5$ \\
\hline CLX & 50000 & 21 & nt & $6.9 \pm 0.7$ \\
\hline SLT & 374 & 9 & nt & $7.8 \pm 0.6$ \\
\hline SAC & 18540 & 5959 & nt & $876 \pm 53$ \\
\hline HCT & 328 & 290 & nt & $7.2 \pm 0.7$ \\
\hline
\end{tabular}

a Human/hp recombinant isozymes, stopped flow $\mathrm{CO}_{2}$ hydrase assay method, from Ref. 6.

b Recombinant hpCA, stopped flow $\mathrm{CO}_{2}$ hydrase assay method, from Ref. 13 .

c This work, mean \pm SE (from three different assays). nt $=$ not tested.

respectively two carbon atoms less compared to 6 . The presence of halogen atoms in the sulfanilamide scaffold, as in 7-10, or the 1,3-disulfamoyl moieties present in $\mathbf{1 1}$ and 12, also is beneficial for the SspCA inhibition, when comparing these compounds to the sulfanilamide 2 scaffold. (iii) A rather large number of the investigated compounds showed excellent SspCA inhibitory action. Indeed, compounds 15-18, AAZ, MZA, EZA, DCP, DZA, BRZ, BZA, TPM, VLX, CLX, SLT and HCT, were low nanomolar inhibitors of this enzyme, with inhibition constants in the range of 4.5$12.3 \mathrm{nM}$ (Table 1). It may be observed that the compounds incorporating a longer molecule, such as 15-19 which are sulfanylated-aromatic/heterocyclic sulfonamides or pyrimidinyl-substituted sulfanilamide (19) as well as the more elaborate heterocyclic or aromatic scaffolds present in most of the clinically used CAIs investigated here, lead to highly effective SspCA inhibitors. It should be also noted that the affinity of many of these sulfonamides/sulfamates to SspCA is many times higher than that for hCA II, a well-known, sulfonamide-'avid' isoform. Furthermore, while hpaCA is significantly inhibited only by acetazolamide ( $\mathrm{K}_{\mathrm{I}}$ of $\left.21 \mathrm{nM}\right)$ and is not very sensitive to other sulfonamides, SspCA has a very distinct inhibition profile compared to this and other bacterial enzyme.

\section{Conclusion}

We investigated sulfonamide/sulfamate inhibition of the $\alpha$-CA from the thermophilic bacterium Sulfurihydrogenibium yellowstonense YO3AOP1 that is catalytically very active for the physiological reaction of $\mathrm{CO}_{2}$ hydration to bicarbonate and protons, and was shown earlier to be highly thermostable. SspCA showed an inhibition profile with these compounds very similar to that of the predominant human cytosolic isoform hCA II, and not to that of the bacterial $\alpha$-CA from Helicobacter pylori. Some clinically used drugs such as acetazolamide, methazolamide, ethoxzolamide, dichlorophenamide, dorzolamide, brizolamide, topiramate, celecoxib and sulthiame were low nanomolar SspCA/hCA II inhibitors $\left(K_{\mathrm{I}} \mathrm{S}\right.$ in the range of 4.5-12.3 nM) whereas simple aromatic/heterocyclic sulfonamides were less effective, but still micromolar inhibitors of this new enzyme. As this highly catalytically active and thermostable CA may show biotechnological applications, its inhibition studies may be relevant for designing on/off systems to control its activity.

\section{Experimental}

\subsection{Chemistry}

Sulfonamides 1-24 and AAZ-HCT were either commercially available (Sigma-Aldrich, Milan, Italy) or prepared as reported earlier by this group. ${ }^{14-18}$

\subsection{Enzyme preparation}

Competent E. coli BL21 (DE3) cells were transformed with the plasmid pET15b containing the Sulfurihydrogenibium $s p$ gene encoding for the acarbonic anhydrase and lacking the signal peptide (first 20 amino acid of the peptide sequence). Cells were grown at $37^{\circ} \mathrm{C}$ and induced with $1 \mathrm{mM}$ IPTG. After additional growth for $5 \mathrm{~h}$, the cells were harvested and disrupted by sonication at $4^{\circ} \mathrm{C}$. Following centrifugation, the cell extract was heated at $90^{\circ} \mathrm{C}$ for $30 \mathrm{~min}$ and centrifuged. The supernatant was loaded into His-select HF Nickel affinity gel and the protein was eluted with $250 \mathrm{mM}$ imidazole. At this stage of purification the enzyme was at least $95 \%$ pure. All the details concerning the expression and purification are described by Capasso C et al. (2012). ${ }^{3}$

\subsection{Enzyme kinetics and inhibition}

An Applied Photophysics stopped-flow instrument has been used for assaying the $\mathrm{CA}$ catalyzed $\mathrm{CO}_{2}$ hydration activity. ${ }^{19}$ Phenol 
red (at a concentration of $0.2 \mathrm{mM}$ ) has been used as indicator, working at the maximum absorbance of $557 \mathrm{~nm}$, with $10-20 \mathrm{mM}$ Hepes (pH 7.5) as buffer, and $20 \mathrm{mM} \mathrm{NaBF}_{4}$ for maintaining constant ionic strength, following the initial rates of the CA-catalyzed $\mathrm{CO}_{2}$ hydration reaction for a period of $10-100 \mathrm{~s}$. The $\mathrm{CO}_{2}$ concentrations ranged from 1.7 to $17 \mathrm{mM}$ for the determination of the kinetic parameters and inhibition constants. For each inhibitor, at least six traces of the initial $5-10 \%$ of the reaction have been used for determining the initial velocity. The uncatalyzed rates were determined in the same manner and subtracted from the total observed rates. Stock solutions of inhibitor $(10 \mathrm{mM})$ were prepared in distilled-deionized water and dilutions up to $0.01 \mathrm{nM}$ were done thereafter with the assay buffer. Inhibitor and enzyme solutions were preincubated at room temperature for 15 min prior to assay, in order to allow for the formation of the E-I complex. The inhibition constants were obtained by non-linear least-squares methods using PRISM 3, whereas the kinetic parameters for the uninhibited enzymes were obtained from Lineweaver-Burk plots, as reported earlier, ${ }^{20,21}$ and represent the mean from at least three different determinations.

\section{Acknowledgments}

This work was financed in part by an FP7 EU project (Metoxia, to CTS and AS) and by a Grant of the 'Accordo di Programma CNR-MSE'.

\section{References and notes}

1. (a) Yang, T.; Lyons, S.; Aguilar, C.; Cuhel, R.; Teske, A. Front. Microbiol. 2011, 2, 130; (b) Kubo, K.; Knittel, K.; Amann, R.; Fukui, M.; Matsuura, K. Syst. Appl. Microbiol. 2011, 34, 293

2. (a) Reysenbach, A. L.; Hamamura, N.; Podar, M.; Griffiths, E.; Ferreira, S.; Hochstein, R.; Heidelberg, J.; Johnson, J.; Mead, D.; Pohorille, A.; Sarmiento, M.; Schweighofer, K.; Seshadri, R.; Voytek, M. A. J. Bacteriol. 1992, 2009, 191; (b) Nakagawa, S.; Shtaih, Z.; Banta, A.; Beveridge, T. J.; Sako, Y.; Reysenbach, A. L. Int. J. Syst. Evol. Microbiol. 2005, 55, 2263; (c) Aguiar, P.; Beveridge, T. J.; Reysenbach, A. L. Int. J. Syst. Evol. Microbiol. 2004, 54, 33; (d) Takai, K.; Kobayashi, H.; Nealson, K. H.; Horikoshi, K. Int. J. Syst. Evol. Microbiol. 2003, 53, 823.

3. Capasso, C.; De Luca, V.; Carginale, V.; Rossi, M. J. Enzyme Inhib. Med. Chem., in press. http://dx.doi.org/10.3109/14756366.2012.703185.

4. Moya, A.; Tambutté, S.; Bertucci, A.; Tambutté, E.; Lotto, S.; Vullo, D.; Supuran, C. T.; Allemand, D.; Zoccola, D. J. Biol. Chem. 2008, 283, 25475.

5. (a) Smith, K. S.; Jakubzick, C.; Whittam, T. S.; Ferry, J. G. Proc. Natl. Acad. Sci. U.S.A. 1999, 96, 15184; (b) Tripp, B. C.; Bell, C. B., 3rd; Cruz, F.; Krebs, C.; Ferry, J.
G. J. Biol. Chem. 2004, 279, 6683; (c) Tu, C.; Tripp, B. C.; Ferry, J. G.; Silverman, D. N. J. Am. Chem. Soc. 2001, 123, 5861.

6. (a) Supuran, C. T. Nat. Rev. Drug Discov. 2008, 7, 168; (b) Supuran, C. T. Bioorg Med. Chem. Lett. 2010, 20, 3467; (c) Supuran, C. T. Curr. Pharm. Des. 2010, 16 3233.

7. a) Supuran, C. T.; Scozzafava, A.; Casini, A. Med. Res. Rev. 2003, 23, 146; (b) Pastorekova, S.; Parkkila, S.; Pastorek, J.; Supuran, C. T. J. Enzyme Inhib. Med. Chem. 2004, 19, 199.

8. (a) Xu, Y.; Feng, L.; Jeffrey, P. D.; Shi, Y.; Morel, F. M. Nature 2008, 452, 56; (b) Viparelli, F.; Monti, S. M.; De Simone, G.; Innocenti, A.; Scozzafava, A.; Xu, Y.; Morel, F. M. M.; Supuran, C. T. Bioorg. Med. Chem. Lett. 2010, 20, 4745; (c) Alterio, V.; Langella, E.; Viparelli, F.; Vullo, D.; Ascione, G.; Dathan, N. A.; Morel, F. M. M.; Supuran, C. T.; De Simone, G.; Monti, S. M. Biochimie 2012, 94, 1232.

9. (a) Domsic, J. F.; Avvaru, B. S.; Kim, C. U.; Gruner, S. M.; Agbandje-McKenna, M.; Silverman, D. N.; McKenna, R. J. Biol. Chem. 2008, 283, 30766; (b) Elleby, B. Chirica, L. C.; Tu, C.; Zeppezauer, M.; Lindskog, S. Eur. J. Biochem. 2001, 268, 1613; (c) Chirică, L. C.; Petersson, C.; Hurtig, M.; Jonsson, B. H.; Borén, T.; Lindskog, S. Biochim. Biophys. Acta 2002, 1601, 192.

10. (a) Supuran, C. T. Front Pharmacol 2011, 2, 34; (b) Schlicker, C: Hall, R. A Vullo, D.; Middelhaufe, S.; Gertz, M.; Supuran, C. T.; Mühlschlegel, F. A Steegborn, C. J. Mol. Biol. 2009, 385, 1207; (c) Zimmerman, S. A.; Ferry, J. G.; Supuran, C. T. Curr. Top. Med. Chem. 2007, 7, 901.

11. Hall, R. A.; Vullo, D.; Innocenti, A.; Scozzafava, A.; Supuran, C. T.; Klappa, P.; Muhlschlegel, F. A. Mol. Biochem. Parasitol. 2008, 161, 140

12. (a) Bertucci, A.; Innocenti, A.; Zoccola, D.; Scozzafava, A.; Allemand, D. Tambutté, S.; Supuran, C. T. Bioorg. Med. Chem. Lett. 2009, 19, 650; (b) Bertucci, A.; Innocenti, A.; Zoccola, D.; Scozzafava, A.; Tambutté, S.; Supuran, C. T. Bioorg. Med. Chem. 2009, 17, 5054; (c) Bertucci, A.; Tambutté, S.; Supuran, C. T.; Allemand, D.; Zoccola, D. Mar. Biotechnol. (NY) 2011, 13, 992.

13. (a) Nishimori, I.; Minakuchi, T.; Morimoto, K.; Sano, S.; Onishi, S.; Takeuchi, H.; Vullo, D.; Scozzafava, A.; Supuran, C. T. J. Med. Chem. 2006, 49, 2117; (b) Nishimori, I.; Minakuchi, T.; Kohsaki, T.; Onishi, S.; Takeuchi, H.; Vullo, D. Scozzafava, A.; Supuran, C. T. Bioorg. Med. Chem. Lett. 2007, 17, 3585; (c) Nishimori, I.; Onishi, S.; Takeuchi, H.; Supuran, C. T. Curr. Pharm. Des. 2008, 14 622 .

14. Ilies, M. A.; Vullo, D.; Pastorek, J.; Scozzafava, A.; Ilies, M.; Caproiu, M. T.; Pastorekova, S.; Supuran, C. T. J. Med. Chem. 2003, 46, 2187.

15. Scozzafava, A.; Briganti, F.; Mincione, G.; Menabuoni, L.; Mincione, F.; Supuran C. T. J. Med. Chem. 1999, 42, 3690.

16. Scozzafava, A.; Menabuoni, L.; Mincione, F.; Briganti, F.; Mincione, G.; Supuran, C. T. J. Med. Chem. 1999, 42, 2641.

17. Supuran, C. T.; Clare, B. W. J. Enzyme Inhib. Med. Chem. 2004, 19, $237-$ 248.

18. Winum, J. Y.; Dogne, J. M.; Casini, A.; de Leval, X.; Montero, J. L.; Scozzafava, A. Vullo, D.; Innocenti, A.; Supuran, C. T. J. Med. Chem. 2005, 48, 2121.

19. Khalifah, R. G. J. Biol. Chem. 1971, 246, 2561.

20. (a) Vullo, D.; Nishimori, I.; Scozzafava, A.; Köhler, S.; Winum, J. Y.; Supuran, C. T. Bioorg. Med. Chem. Lett. 2010, 20, 2178; (b) Kolayli, S.; Karahalil, F.; Sahin, H. Dincer, B.; Supuran, C. T. J. Enzyme Inhib. Med. Chem. 2011, 26, 895; c Maresca, A.; Vullo, D.; Scozzafava, A.; Supuran, C.T. J. Enzyme Inhib. Med. Chem., in press. http://dx.doi.org/10.3109/14756366.2011.649268.

21. (a) Innocenti, A.; Scozzafava, A.; Supuran, C. T. Bioorg. Med. Chem. Lett. 1855 2009, 19; (b) Temperini, C.; Scozzafava, A.; Supuran, C. T. Bioorg. Med. Chem. Lett. 2010, 20, 474. 